\title{
INFORMAL SECTOR CITY TOURISM: CROSS-BORDER SHOPPERS IN JOHANNESBURG
}

\author{
Christian M. ROGERSON* \\ University of Johannesburg, School of Tourism \& Hospitality, College of Business \& \\ Economics, Bunting Road, Johannesburg, South Africa, email: crogerson@uj.ac.za
}

\begin{abstract}
Citation: Rogerson, C. M. (2018). INFORMAL SECTOR CITY TOURISM: CROSS-BORDER SHOPPERS IN JOHANNESBURG. GeoJournal of Tourism and Geosites. 22(2), 381-392. https://doi.org/10.30892/gtg.22209-296
\end{abstract}

\begin{abstract}
Informality is a distinguishing trait of economic life across much of the global South. In terms of the tourism sector several researchers examine the informal sector of leisure tourism. In this article the aim is to focus upon business tourism and more specifically the segment of informal sector business tourism. The growth of informal sector business tourism is particularly important in sub-Saharan Africa. An analysis is undertaken of recent research on South Africa's major city of Johanesburg where the importance of informal sector business tourism is demonstrated. The results show Johannesburg is the focus for transnational entrepreneurship in the form of the growth of cross-border shopping. The organisation of this manifestation of informal business tourism, the nature of its participants and business challenges form the focus of discussion. It is argued that despite many benefits that flow to the city of Johannesburg from informal sector of business tourism the local state has yet to fully acknowledge the multiple positive impacts of these international visitors upon the urban economy and plan to accommodate the needs of cross-border shoppers.
\end{abstract}

Key words: informal sector tourism; business tourism; migrant entrepreneurs; cross-border shopping; Johannesburg

\section{INTRODUCTION}

Informality is a distinguishing trait of daily economic life across much of the global South. Although the precise definition of the term 'informality' is contested usually it applies to "a range of behaviours and practices that are not regulated or controlled by the state or formal institutions, including those related to income generation, service provision and settlements" (Chen et al., 2016: 336). In particular, across sub-Saharan Africa the historically unique aspect of labour markets is the extent of such informality (Golub \& Hayat, 2014). Several studies attest to the fact that the informal economy is "a major force" across Africa (Benjamin \& Mbaye, 2014: 1). Grant (2015: 135) contends that the mass of urban dwellers in Africa "work outside of the formal economy, live in informal housing, and conduct business without using banks". Employment in the continent "remains overwhelmingly informal" accounting for at least 80 percent of total employment (Golub \&

\footnotetext{
* Corresponding author
} 
Hayat, 2014: 2). Across Africa a substantial proportion of the urban poor pursue livelihoods which are carved out of gaps in formal rules and of gaps in the use of (especially) urban space both of which are defined by local states (Chen et al., 2016; Rogerson, 2016a).

Arguably, informality is a dimension of all sectors of the economy including of the continent's expanding tourism sector (Rogerson \& Rogerson, 2018). The objective in this paper is to investigate one distinctive facet of the informal economy of tourism in Africa and of the multiple challenges confronting a particular sub-group of informal tourism entrepreneurs. The cosmopolitan city of Johannesburg, South Africa's leading commercial centre, major locus of corporate headquarters and the country's second most significant destination for tourism spend (following Cape Town) provides the canvas for this investigation (Rogerson \& Rogerson, 2014, 2015, 2017; Rogerson, 2018). Despite its economic strength the labour-absorptive capacity of Johannesburg's formal economy cannot match the numbers of potential work seekers, not least because Johannesburg is quintessentially a city which is a magnet for migrants (Peberdy, 2013; Rogerson \& Rogerson, 2015). The city evidences a substantial and expanding informal economy which operates mostly on the street as well as inside multi-storey buildings, from backyard shacks, converted garages and resident home spaces. Recent surveys suggest that during 201311 percent of Johannesburg city residents owned a business and 65 percent of all business owners functioned in the informal economy. Peberdy (2016: 9) shows that in Johannesburg "retail is easily the most important entrepreneurial activity" and encompasses the sale of a variety of foodstuffs, clothes, alcohol, shoes, electrical goods, DVDs and soft furnishings. One striking component of this informal retail economy is the operations of the city's communities of international migrant entrepreneurs who were attracted to Johannesburg by potential economic opportunities that opened up especially since 1994 during the postapartheid period (Crush \& McDonald, 2000). The largest share of these migrant entrepreneurs in Johannesburg is drawn from the proximate states of the Southern African Development Community, with Zimbabwe and Mozambique the two leading individual country sources (Peberdy, 2017). Chen et al. (2016) point out that the policies and practices of local government exert a substantial impact on urban informal livelihoods. Of note is that the local state in Johannesburg assumes a critical role in regulating the activities of the city's informal entrepreneurs. At various times it has vacillated between a rhetoric of support for such entrepreneurs to the implementation of highly repressive measures which have threatened and even at times destroyed precarious informal livelihoods (Rogerson, 2016b).

In terms of the city's tourism economy Johannesburg is best understood as a 'nontraditional' destination in which business tourism assumes a critical role, albeit with some recent expansion occurring in the city's leisure offerings (Rogerson, 2002, 2013; Rogerson \& Rogerson, 2016). Visiting friends and relatives constitutes the largest actual number of recorded trips to Johannesburg but business tourism is the key to high levels of tourism spend in the city (Rogerson \& Rogerson, 2014, 2017). Concerning the uneven geography of business tourism in South Africa, Johannesburg is the country's leading focus for informal as well as formal sector business tourism because of the extensive operations there of communities of cross-border shoppers from surrounding countries (Rogerson, 2015a). The organisation, characteristics and challenges of these cross-border shoppers are under scrutiny in this article. The discussion falls into two further sections of material. First, the study is situated more broadly within existing literature around informal sector tourism, particularly in the context of the global South and thereafter an exploration of the distinctive nature of informal sector business tourism in Africa. Second, attention turns to examine the nature of cross-border shoppers/traders, which constitute such a significant component of the informal economy of inner-city Johannesburg, the organisation of their businesses, and of challenges confronting these entrepreneurs. The findings are 
triangulated from a number of recent empirical investigations which have been conducted around cross-border shopping in Johannesburg. The analysis is informed overall by the observation made by Nunkoo et al. (2013:5) that "a review of past research efforts is an important endeavour in all academic research areas", not least in tourism scholarship.

\section{THE INFORMAL SECTOR OF TOURISM}

Tourism scholars 'discovered' and began applying the concept of the informal sector to tourism research several years after the term was first introduced into the lexicon of development studies by the ILO (1972) and Hart's (1973) benchmark study on Ghana. In one of the earliest statements on its application Davis (1978: 303) observed that the tourism industry in developing countries could be appropriately differentiated between formal and informal activities with the latter dominated by "the underemployed residue" left over by dualistic development trajectories under the guise of 'modernization'. Using the ILO's classification of the characteristics of formal versus informal sector enterprises Wahnschafft (1982) sought to explore the socio-economic structure of a tourist resort in terms of the formal-informal dichotomy. In this highly influential study of Pattaya, Thailand it was observed that "the ILO has submitted neither particular studies nor policy recommendations with regard to the special case of the informal tourism sector" (Wahnschafft, 1982: 433). At Pattaya the informal tourism economy was comprised of informal transport operators, selfemployed beach vendors, handicraft producers and the resort's thriving economy of prostitution. An important finding was that government tourism policy was biased towards support for and protection of formal tourism enterprises and that "informal businesses are frequently subjected to regulations that are meant to assure their effective functioning according to the needs of the formal sector" (Wahnschafft, 1982: 449).

The subordinated nature of informal tourism enterprises in the global South was confirmed by several other investigations. Oppermann (1993: 542) conjectured that government bias towards formal sector enterprises might "eventually lead to an extinction of the informal resort sector". Cukier and Wall (1994: 464) stressed that in Bali the role and importance of the informal tourism economy "is often ignored by tourism planners". In Sri Lanka an examination of the ordinary lives of street guides disclosed that most were living off their wits by "seizing opportunities as and when they occur" (Crick, 1992:139). At Kandy the marginal lives and existence of these street guides was exposed by Crick (1992: 138) who highlighted that in Sri Lanka "to tourism planners and policy makers the poor are normally just a nuisance". The neglect by planners of the informal sector in tourism and of its participants is a recurrent theme in other studies which appeared about beach masseurs, craft souvenir traders, or providers of (unlicensed) informal accommodation (Farver, 1984; Timothy \& Wall, 1997; Dahles, 1998; Dahles \& Bras, 1999a, 1999b; Dahles, 2001; Dahles \& Keune, 2002; Hampton, 2003). Notwithstanding the increasing number of tourism plans prepared in developing countries it was stressed by Timothy \& Wall (1997: 324) that "very few such plans address the needs of the informal sector or even acknowledge its existence". Overall, the stance of officialdom was often that the informal sector and its participants was 'temporary' which provided a rationale for planners to conveniently neglect its needs. One important underpinning for this policy viewpoint was that (with the notable exception of sex workers) "the informal sector, including informal vendors, has not received attention in the tourism literature commensurate with its importance" (Timothy \& Wall, 1997: 325).

In addressing this oversight through an examination of street vendors in Yogyakarta, Indonesia Timothy and Wall (1997) documented a heterogeneous group of street sellers who exhibited many of the ILO's characteristics for informal enterprises. The strong local linkages of these vendors was isolated as a positive force for local 
economic development. Nevertheless, these informal tourism entrepreneurs were "often viewed as a problem by tourism planners" (Timothy \& Wall, 1997: 337). Overall, it was concluded that the informal sector of tourism should not be viewed as "a set of aberrant activities which will disappear with modernization" rather it needs to be understood as a fundamental structural feature of tourism in countries across the global South (Timothy \& Wall, 1997: 337). Oppermann's works (1993, 1998) direct our attention to the organisation of tourism space in developing countries. In particular, it was emphasized that the dual structure of the tourism economy "manifests itself in space with the corresponding economic and sociocultural impacts" (Oppermann, 1993: 545). It was argued that one could discern so-termed formal tourism space, a shared space of formal and informal tourism enterprises, and a zone of exclusively informal tourist space. A significant finding was that the informal tourism sector "is characterized through its high integration into the local economic structure that results in a low leakage and, therefore, a high multiplier effect on the local economy" (Oppermann, 1993: 331).

Since 2000 there has been a maturation of tourism research concerning the informal sector. The emerging scholarship around pro-poor tourism engaged with issues of upgrading opportunities for informal sector enterprises (Ashley \& Roe, 2002; Rogerson, 2006; Mitchell \& Ashley, 2010). Bah \& Goodwin (2003) examined increasing access of the informal sector to market opportunities in tourism in The Gambia and showcased the potential for a range of win-win partnerships between the formal and informal sector enterprises. The need for such partnerships and of improved relationships between the formal economy and informal enterprises was a theme identified also in Henderson and Smith's (2009) analysis of two beach resorts in Thailand. In research on sub-Saharan Africa Meyer (2013: 786) recorded the role of international migrants in the informal economy of Stonetown, Zanzibar where it was disclosed that informal art sellers "are mainly Kenyans dressed in Maasai attire selling Maasai souvenirs despite the fact that Zanzibar has no obvious relation to Maasai culture”. In Tanzania Slocum et al. (2011) argued that current policy agendas towards the 'formalization' of informal enterprises negated the economic benefits of tourism development pathways in the country. In recent research several new issues have been scrutinised concerning informal tourism enterprises. The theme of formalization of the informal sector and the contribution of poor urban vendors to tourism development in Manila, Philippines is taken up by Yotsumoto (2013). Truong (2018) explores the perspectives and experiences of street vendors in Hanoi, Vietnam regarding tourism and poverty alleviation. Biggs et al. (2012) analyse the resilience of informal (as well as formal) tourism enterprises to natural disasters through the lens of reef tourism in Phuket, Thailand. Further, Damayanti et al. (2017) utilise the concept of 'coopetition', defined as the simultaneous cooperative and competitive activities among actors, to revisit the organisation and workings of the informal tourism economy of Yogyakarta, Indonesia.

Overall, in observing the current state of research on the informal tourism economy it is evident there is an almost exclusive focus on enterprises and activities that are associated with leisure tourism. Only a limited scholarship exists that engages with the informal economy in non-leisure forms of tourism, not least of business tourism. Mainstream scholarship around business tourism in the global North centres upon a definition as encompassing independent business trips and travelling for purposes of meetings, incentives, conferences and exhibitions or MICE tourism (Davidson, 1994). As is argued elsewhere, at the heart of Northern literature about business tourism is the 'formal sector' business tourist engaged in travelling for business purposes usually on an international basis and sometimes also as a domestic business traveller (Rogerson, 2015b). Focus issues for research include, inter alia, the establishment of convention centres, decision-making and marketing for conferences or exhibitions, the travel behaviour and accommodation 
preferences of MICE tourists, and research on the local economic impacts of MICE tourism (Weber \& Chon, 2002; Ladkin, 2006; Celuch \& Davidson, 2009; Horvath, 2011). Throughout sub-Saharan Africa there is a substantial informal business economy which coexists with a formal business tourism economy paralleling that of the global North (Rogerson, 2015b; Rogerson \& Letsie, 2015; Tichaawa, 2017). The formal business economy in Africa is reflected in the appearance of convention centres and clusters of upmarket accommodation services which are targeted at the business traveller and mainly situated in capital cities or major commercial centres (Greenberg \& Rogerson, 2015; Rogerson, 2011a, 2011b, 2013a, 2013b; Tichaawa, 2017). This said, in a seminal paper it was argued the inclusion of business travel in the scope and realm of global tourism scholarship was in essence a 'Northern concept' and centred mainly on affluent business people travelling either between developed countries or between the developed and the developing worlds (Timothy \& Teye, 2005). This Northern definition of business tourism overlooks a vast array of informal sector business travel and tourists - international and domestic - which are a vital dimension of business tourism in Africa (Rogerson \& Letsie, 2015). Timothy \& Teye (2005: 83) issued a call for researchers to challenge the conventional view of business travel in tourism by highlighting the business operations of traders and vendors traversing borderland spaces in West Africa and yet unenumerated as tourists.

Manifestations of such cross-border trading are recorded throughout most of subSaharan Africa (Peberdy, 2000a, 2000b, 2007; Afrika \& Ajumbo, 2012; Brenton \& Gamberoni, 2013; Peberdy et al., 2015; Dobler, 2016; Tichaawa, 2017). In particular, the sub-region of Southern Africa has witnessed a major burst of such activities. It is evidenced that this kind of informal business tourism is a common phenomenon between South Africa and other countries in Southern Africa, most importantly Lesotho, Swaziland, Mozambique, Zimbabwe, Zambia and Malawi (Muzvidziwa, 1998; Peberdy \& Crush, 1998; Peberdy, 2000a, 200ob; Peberdy \& Crush, 2001; Peberdy \& Rogerson, 2003; SBP, 2006; ComMark Trust, 2008; Masango \& Haraldsson, 2010; Muzvidziwa, 2010; Rogerson, 2011; Chiliya et al., 2012; Jamela, 2013; Peberdy et al., 2015; Manjokoto \& Ranga, 2017). Indeed, Peberdy et al. (2015: 207) assert that informal sector crossborder trade represents "a significant feature of regional trade flows in Southern Africa". For Timothy and Teye (2005: 83) the activities of such cross-border traders constitute a "form of business traveller that is unique to the developing world".

\section{CROSS BORDER TRADERS AND SHOPPERS IN JOHANNESBURG}

South Africa's transition to democracy and the country's re-integration into the global economy post-1994 after years of international boycotts and sanctions created a radical shift in the socio-political environment which impacted regional mobilities. Crush and McDonald (2000: 4) reflected that one of the most notable post-apartheid changes was "the sheer volume and diversity of human traffic now crossing South Africa's borders". Indeed, whilst the abandonment of international sanctions often is linked to expanding international tourism flows to South Africa from Europe and North America it must be understood that the most dramatic shift was the massive surge which occurred in flows of regional African tourists (Rogerson, 2004). Of South Africa's 9 million recorded international tourists nearly 80 percent of visitors are from the region of sub-Saharan Africa with the largest flows from surrounding countries in the Southern African Development Community (SADC) (Rogerson, 2011). In terms of business travel the demise of apartheid "inserted South Africa into regional and trans-continental informal trade networks" (Crush \& McDonald, 2000: 5). The central drivers of informal sector business tourism are communities of international migrant entrepreneurs who are cross-border traders (Peberdy \& Rogerson, 2000, 2003; Peberdy et al., 2015). From the earliest investigations of these 
entrepreneurs there is evidence that the rise of cross-border trading certainly pre-dates the demise of apartheid (Peberdy \& Crush, 1998; Peberdy, 2000a, 200ob; Peberdy \& Crush 2001). For example, Peberdy and Crush (1998, p. 2) reported that "most traders from the SADC region have been travelling to South Africa to trade since at least 1990, and some before". Nevertheless, the changed politico-economic environment post-1994 provided a massive stimulus for further expansion. These communities of migrant entrepreneurs have been shown as connected to strong informal and formal transnational networks of trade, migration and entrepreneurship (Peberdy \& Rogerson, 2000, 2003). The activities of these traders carrying goods across international borders are considered "the predominant form of employment-related non-permanent migration in the region" (Nunez, 2009: 9). In one analysis these informal business tourists in South Africa are viewed as "amongst the most enterprising and energetic of contemporary migrants” (Crush et al., 2015).

The category of informal cross-border trader is not, however, homogeneous. In Southern Africa, at least five different variations of cross-border trading can be discerned (Peberdy, 2002). The most numerous are shoppers who travel to South Africa for short periods (usually 1 to 4 days) in order to buy goods from formal sector retail and wholesale outlets for purposes of resale in the home country variously on the street, in markets, to individuals and to formal sector retail establishments. Second, are communities of traders who travel for longer periods to South Africa - from one week to up to two months carrying goods (often food or handicrafts) from the home country in order to sell in informal and retail markets. The profits from those goods are then spent on purchasing goods in South Africa for transfer and resale in the home country. Third, are traders who travel across three countries, including South Africa, to buy and sell goods on their journey. Four and five are the smallest groups and comprise respectively traders who only bring goods from the home country into South Africa for sale and South Africans who take goods for vending in other countries in the Southern African region.

Although the geography of cross-border trading in South Africa includes a number of border towns, most notably Musina on the Zimbabwe-South Africa border, Johannesburg is the main focus of operations (Rogerson, 2011). Traders are lured to Johannesburg by the variety and prices of goods that can be purchased through an estimated 3000 shops in inner city Johannesburg which service this trade (Tanya Zack Development Planners et al., 2017). Recently, of critical importance for Johannesburg's position as a hub of cross-border trading from other countries in sub-Saharan Africa, including as far north as Malawi and Zambia, has been the establishment of several malls run by Chinese entrepreneurs. The development of these Chinese malls initially in the inner city but subsequently at other locations in Johannesburg was a response by Chinese entrepreneurs to increasing threats to businesses in the inner-city from high levels of crime. Clustering of independent businesses in these malls increased safety for shoppers and Chinese entrepreneurs. The commodities offered in these China Malls are mainly low priced Chinese imports with the dominant product clothing as well as footwear, baby goods, toys, homeware and electrical goods (Tanya Zack Development Planners et al., 2017).

Participation in the business of cross-border trading is driven by a range of factors. Nunez (2009: 10) argues that in several of the proximate countries to South Africa "the economic necessity to undertake this form of entrepreneurship is compounded by a lack of formal sector employment; many people get involved in informal cross-border trading activities as a response to unemployment". Arguably, the absence of formal wage employment opportunities in home countries is the core reason for participating in this form of trade. In Zimbabwe in particular the implementation of successive Structural Adjustment Programmes resulting in major job losses and deindustrialization forced a search for alternative income/livelihood strategies (Jamela, 2013; Manjokoto \& Ranga, 
2017; Tawodzera \& Chikanda, 2017). Chikanda and Tawodzera (2017: 10) revealed that the largest proportion of cross-border traders from Zimbabwe commenced business operations "during and after the economic crisis of 2008, with nearly three-quarters starting up between 2006 and 2014". During this period cross border trading escalated "as thousands of jobless workers had no choice but to enter the informal economy" (Tawodzera \& Chikanda, 2017: 912). Overall, as has been shown in several research studies the business of cross-border trading represents an important source of self-employment and income generation for those without recourse to formal wage employment (Peberdy \& Crush, 1998; Chiliya et al., 2012; Jamela, 2013; Peberdy et al., 2015; Chikanda \& Raimundo, 2017; Tawodzera \& Chikanda, 2017). This said, in the context of escalating economic crisis and hardship in Zimbabwe, many of those people in formal employment - especially civil servants and teachers - sought to combine cross border trading with their formal job in order to supplement salaries that were inadequate for household needs (Manjokoto \& Ranga, 2017). Given low levels of formal wages in public service in Mozambique crossborder trading was observed as offering an income opportunity which could yield returns of "more than four times the minimum salary in the formal sector" (Nunez, 2009: 10).

In terms of exploring further who are the participants in cross-border trading, traditionally this form of entrepreneurship has been viewed as almost exclusively the domain of women who are channeled into this as "a survival strategy because of labour market discrimination" (Peberdy et al., 2015: 212). Typically, Masango and Haraldsson (2010: 2) draw attention to a "significant growth" of informal cross-border trading and that these informal business tourists, albeit acknowledged as a diverse constituency, are "generally dominated by women". This picture of poor mainly women traders in search of a source of business income and employment is reinforced also by findings from research by Muzvidziwa (1998, 2010), Jamela (2013), Brenton and Gamberoni (2014) and, by Manjokoto and Ranga (2017). Several investigations point to the fact that the groups of women traders often comprise "the vulnerable, unemployed, orphans, refugees, the youth, school leavers and widows among others" (Masango \& Haraldsson, 2010: 2). New research from the Southern African Migration Programme suggests, however, that this 'gendered' character of cross-border trading to South Africa is changing and that the situation is more nuanced with a much higher level of participation by males than previously thought (Peberdy et al., 2015). From a large-scale survey undertaken of crossborder traders crossing into South Africa from Botswana, Lesotho, Mozambique, Swaziland and Zimbabwe at six different border posts it was disclosed that considerable variations existed in the ratio of male to female traders (Peberdy et al., 2015). The broad result was that women comprised 63 percent of the cohort of informal cross-border traders albeit considerable variations were recorded between different border crossings with a range from 83.5 percent women from Swaziland as compared to only 48.o percent from Lesotho. In the case of Mozambique the dominance of women in the trade is explained by Chikanda and Raimundo (2017: 948) inter alia "to their long experience in crossing borders dating back to the early days of Mozambique's 16 year civil war; their business acumen; their familiarity with managers of wholesale storehouses in Johannesburg; and the fact that they find it more difficult than men to access formal employment”. By contrast, at the important Zimbabwe border crossing men comprised almost half the total cohort of traders, a finding which is explained by the country's severe economic crisis and extraordinary high levels (estimated up to 80 percent) of unemployment (Peberdy et al., 2015; Tawodzera \& Chikanda, 2017). This suggests increasingly men may be entering into the business of cross-border trading in Southern Africa, now in competition with and potentially threatening to displace women traders more especially in the most lucrative spheres of this type of informal entrepreneurship. 
One consistent finding across surveys of cross-border trading is its dominance by young adults which is accounted for "by the arduous nature of the trade, which involves a great deal of travelling and spending considerable time waiting at border posts and the places where goods are sourced" (Tawodzera \& Chikanda, 2017: 915). Another common observation is that many traders are not simply "ill-educated people seeking to survive but are more likely to be relatively well-educated entrepreneurs seeking business opportunities" (Peberdy \& Crush, 1998: 5). Indeed, in the example of Zimbabwe, the entry of better-educated people into cross-border trading, either as main occupation or for supplementary household income source, is a direct consequence of the persistent economic hardships and high levels of unemployment in the final chaotic years of former President Robert Mugabe. The shifting complexion of informal cross-border trading from Zimbabwe is summarized by Tawodzera and Chikanda (2017: 916) as follows "an economic activity once completely dominated by low-income households and a relatively uneducated population has become a viable alternative for others reeling under economic pressure".

Arguably, whilst the majority of cross-border traders in Southern Africa are necessity-driven entrepreneurs there is a small but notable component of (better educated often male) opportunity-driven entrepreneurs motivated by desires to run their business, prestige or enhanced status in local communities (Chikanda \& Tawodzera, 2017). The rhythm of cross-border trading is well-documented and reveals a complex variety of business mobilities which varies through different crossing points (Peberdy, 2007; Peberdy et al., 2015). Length of stay was impacted variously by whether traders primarily crossed borders in order simply to shop for resale in the home country or whether they were in South Africa to sell goods from the home country which requires a longer duration of stay. As a rule, length of stay tends to be as short of possible because of cost considerations especially concerning accommodation. Frequency of visits by traders to South Africa differs greatly between border crossings with reports that traders from Mozambique undertake weekly visits whereas for those coming through more distant borders patterns of visits were fortnightly or monthly (Peberdy et al., 2015). Overall, the generally longer stay recorded by Zimbabwean traders is related to both longer distances and the fact that the majority are coming to sell as well as to purchase goods (Chikanda \& Tawodzera, 2017).

During 2017 the most recent large-scale survey of cross-border shoppers/traders in Johannesburg was undertaken. Its central results in terms of the nature of the traders, how they organise their visits, products purchased and organization of shopping are summarized on Table 1. Overall, these findings confirm many of the characteristics and organizational issues raised in other recent research reported here by the Southern African Migration Project. This said, there are certain differences, most notably in terms of the proportion of male to female traders. What this points to is the existence potentially of differences in cross-border trader communities not only in terms of different border crossings but also in terms of the destinations for these traders/shoppers. Finally, some brief comments on the business challenges that confront these informal business tourists in South Africa. At startup of business whilst the amount of capital needed is relatively small to engage in crossborder shopping many traders expressed that it was a challenge. In the case of Zimbabwean traders most obtained start-up capital from personal sources with additional funding secured by loans from friends and relatives; only a small number use loans from either micro-finance institutions or banks (Chikanda \& Tawodzera, 2017). In conducting their businesses in South Africa several other challenges arise. For Zimbabweans critical issues can be the cost and time to secure a passport, long delays at border posts, high duties, restrictions imposed on the export-import of certain commodities and corrupt officialdom at customs and immigration. Verbal and sometimes physical harassment is also reported as of concern at border entry/exit (Tawodzera \& Chikanda, 2017). 
Informal Sector City Tourism: Cross-Border Shoppers in Johannesburg

Table 1. : Profile of Cross-Border Shoppers in Johannesburg

(Source: Author adapted from Tanya Zack Development Planners et al., 2017)

\begin{tabular}{|l|l|}
\hline \multicolumn{1}{|c|}{ Characteristics } & \multicolumn{1}{|c|}{ Key Findings } \\
\hline Demography & $28.4 \%$ Male, 71.6\% Female; Average Age 37 \\
\hline Highest Education & $\begin{array}{l}22.4 \text { \% tertiary qualification, 33.7\% Matric or equivalent, 35.9\% } \\
\text { secondary education, 8\% primary }\end{array}$ \\
\hline $\begin{array}{l}\text { Length of time as } \\
\text { trader }\end{array}$ & $\begin{array}{l}\text { Majority shopping in Johannesburg regularly for between 5 and 7 years; 13\% for } \\
\text { less than one year; maximum recorded is 31 years as trader. }\end{array}$ \\
\hline Knowledge of Business & 82\% learned from family or friends \\
\hline $\begin{array}{l}\text { Mode of travel to } \\
\text { Johannesburg }\end{array}$ & $\begin{array}{l}\text { 65\% by bus. 33 \% by minibus taxi; average travel time by bus 31 hours, } \\
\text { by minibus taxi 7 hours }\end{array}$ \\
\hline $\begin{array}{l}\text { Major products } \\
\text { purchased }\end{array}$ & $\begin{array}{l}\text { New clothing, household goods, new shoes, bags and handbags, personal } \\
\text { care products, electronics }\end{array}$ \\
\hline Shopping strategy & $\begin{array}{l}\text { For safety and financial reasons 60\% shop in groups, 40\% on own; 24 \% } \\
\text { buy collectively as a group }\end{array}$ \\
\hline Choice of goods & $\begin{array}{l}\text { 48\% decide what to shop for by taking orders in the home country, 22\% are led } \\
\text { by what sells best at home and 23\% view what is available in Johannesburg. }\end{array}$ \\
\hline Frequency of visits & $\begin{array}{l}\text { Over half of traders visit Johannesburg more than 10 times a year; 41 \% } \\
\text { visit once a month. }\end{array}$ \\
\hline Payments & $\begin{array}{l}\text { For 95 \% traders this is a cash economy. Shoppers tend to minimize } \\
\text { spending in Johannesburg on food, accommodation or other expenses } \\
\text { and maximise expenditures on goods }\end{array}$ \\
\hline
\end{tabular}

Xenophobia in South Africa towards non-South Africans is a further problem for these traders. Safety issues and crime in inner-city Johannesburg are major business challenges. Chiliya et al. (2012) highlight that shoppers are often assaulted and robbed of their possessions and highly vulnerable to theft of cash and goods because of operating on a cash only basis and often carrying large volumes of stock (Table 1). The most recent survey concluded that the "risk of a cross border shopper being a victim of crime in the inner city of Johannesburg is extremely high" (Tanya Zack Development Planners et al., 2017: 126). At the Zimbabwe-South Africa border the women traders are exposed to multiple difficulties in terms of sexual harassment by custom officials (Richter et al., 2014). In addition, because of the high costs of safe accommodation, often the women put themselves at risk of being robbed or raped either by sleeping in the open or at bus stations. Overall, because of its negative impacts on women's lives, for Manjokoto and Ranga (2017: 37) this informal business tourism is "unhealthy physically, socially, emotionally and spiritually" for many women traders.

\section{CONCLUSION}

Informality is a distinctive facet of tourism economies in the developing world or global South. The informal sector of leisure tourism is garnering growing attention from tourism scholars. In this analysis attention was directed to the much less well documented informal economy of business tourism which is particularly significant in sub-Saharan Africa. As argued by Rogerson and Saarinen (2018) business travel is a critical motivation for the poor to be tourists. The business activities of traders and shoppers who cross international borders constitute a major element in inter-African trade. Over recent years the region of Southern Africa has emerged as the largest focus for cross-border traders or shoppers. The city of Johannesburg in South Africa has become established as the shopping hub of sub-Saharan Africa. Communities of crossborder shoppers mainly from surrounding countries in the Southern African Development Community are attracted to the city by the variety of goods and price competitiveness of products that can be purchased. Despite many benefits that flow to 
the city of Johannesburg from this informal sector of business tourism - including job creation in retailing, transport and hospitality - the local state has yet to fully acknowledge the multiple positive impacts of these international visitors upon the urban economy. Urban planning in Johannesburg must acknowledge the city's significance as an international retail hub by physical planning interventions strategically targeted to upgrade infrastructure to support these shoppers. In addition, it must address several of the factors which currently are negatively impacting shopping in the inner city, most importantly issues of safety and crime. In this respect some planning lessons can be drawn from the experience in other parts of the world for addressing infrastructural issues and criminality in inner cities (Chen et al., 2016; Matlovičová et al., 2016; Tanya Zack Development Planners et al., 2017).

\section{REFERENCES}

Afrika J-G.K., \& Ajumbo, G. (2012). Informal cross border trade in Africa: implications and policy recommendations. African Development Bank, Tunis.

Ashley, C., \& Roe, D. (2002). Making tourism work for the poor: Strategies and challenges in Southern Africa. Development Southern Africa, vol. 19, 61-82.

Bah, A., \& Goodwin, H., (2003). Improving Access for the Informal Sector to Tourism in Gambia. Working Paper No. 15, Overseas Development Institute, London.

Benjamin, N., \& Mbaye, A.A., (2014). Informality, growth and development in Africa, United Nations University-WIDER Working Paper 2014/o52, Helsinki.

Biggs, D., Hall, C.M., \& Stoeckl, N., (2012). The resilience of formal and informal tourism enterprises to disasters: Reef tourism in Phuket, Thailand, Journal of Sustainable Tourism, vol. 20, 645-665.

Brenton, P., \& Gamberoni, E., (2013). Introduction. In: Brenton, P, Gamberoni, E., Sear, C. (eds.), Women and Trade in Africa: Realizing the Potential, The World Bank, Washington DC, 1-26.

Celuch, K., \& Davidson R., eds. (2009). Advances in business tourism research: a selection of papers presented at ATLAS Business Tourism Special Interest Group meetings, ATLAS, Arnhem.

Chen, M., Roever, S., \& Skinner, C., (2016). Urban livelihoods: Reframing theory and policy, Environment and Urbanization, vol. 28, no. 2, 331-342.

Chiliya, N., Masocha, R., \& Zindiye S., (2012). Challenges facing Zimbabwean cross border traders trading in South Africa: A review of literature, Chinese Business Review, vol. 11, 564-570.

Chikanda, A., \& Raimundo, I., (2017). Informal entrepreneurship and cross-border trade between Mozambique and South Africa, African Human Mobility Review, vol. 3, no. 2, 943-974.

Chikanda, A., \& Tawodzera, G., (2017). Informal Entrepreneurship and Cross-Border Trade Between Zimbabwe and South Africa, Southern African Migration Programme Migration Policy Series No. 74, Cape Town.

Commark Trust, (2008). Giving development a face - cross border shopping, ComMark Trust, Johannesburg.

Crick, M. (1992). Life in the informal sector: Street guides in Kandy, Sri Lanka, In: Harrison, D. (ed.), Tourism and the less developed countries, Belhaven, London, 135-147.

Crush, J., \& McDonald, D.A., (2000). Transnationalism, African immigration, and new migrant spaces in South Africa: an introduction, Canadian Journal of African Studies, vol. 34, no. 1, 1-19.

Crush, J., Williams, V., \& Peberdy, S. (2005). International migration and development: Dynamics and challenges in South and Southern Africa. Paper prepared for the United Nations Expert Group Meeting on International Migration and Development, United Nations Department for Economic and Social Affairs 6-8 July, New York.

Cukier, J., \& Wall, G. (1994). Informal tourism employment: Vendors in Bali, Indonesia, Tourism Management, vol. 15 , no. $6,464-467$.

Dahles, H., (1998). Tourism, government policy and petty entrepreneurs, South East Asian Research, vol. 6, 73-98.

Dahles, H., (2001). Tourism, Heritage and National Culture in Java, Curzon, Richmond.

Dahles, H., \& Bras, K., eds, (1999a). Tourism and Small Entrepreneurs: Development, National Policy and Entrepreneurial Culture - Indonesian Cases, Cognizant Communication, New York.

Dahles, H., \& Bras, K. (1999b). Entrepreneurs in romance: Tourism in Indonesia, Annals of Tourism Research, vol. 26, 267.

Dahles, H., \& Keune, L. (2002). Tourism Development and Local Participation in Latin America, Cognizant Communication, New York.

Damayanti, M., Scott, N., \& Ruhanen, L. (2017). Coopetitive behaviours in an informal tourism economy, Annals of Tourism Research, vol. 65, 25-35.

Davidson, R., (1994). Business Travel, Pitman, London.

Davis, D., (1978). Development and the tourist industry in third world countries, Society and Leisure, 1, p. 301-322.

Dobler, G., (2016). The green, the grey and the blue: A typology of cross-border trade in Africa, Journal of Modern African Studies, vol. 54, no. 1, 145-169. 
Farver, J.A.M., (1984). Tourism and employment in the Gambia, Annals of Tourism Research, vol. 11, 249-265. Grant, R., (2015). Africa: Geographies of change, Oxford University Press, New York.

Greenberg, D., \& Rogerson, J.M. (2015). The serviced apartment industry of South Africa: A new phenomenon in urban tourism, Urban Forum, vol. 26, no. 4, 467-482.

Hampton, M.P. (2003) Entry points for local tourism in developing countries: Evidence from Yogyakarta, Indonesia, Geografiska Annaler, vol. 85B, 85-101.

Hart, K., (1973). Informal income opportunities and urban employment in Ghana, Journal of Modern African Studies, vol. 11, 61-89.

Horvath, Z., (2011). The economic impacts of conference tourism in Siofok, the 'capital' of Lake Balaton, GeoJournal of Tourism and Geosites, vol. 7, no. 1, 75-86.

International Labour Office, (1972). Employment, Incomes and Equality: A Strategy for Increasing Productive Employmrnt in Kenya, International Labour Office, Geneva.

Ladkin, A. (2006). Conference tourism - MICE market and business tourism, In: Buhalis, D., Costa, C. (eds.), Tourism business frontiers: consumers, products and industry, Elsevier, Amsterdam, 56-66.

Manjokoto, C., \& Ranga, D., (2017). Opportunities and challenges faced by women involved in informal crossborder trade in the city of Mutare during a prolonged economic crisis in Zimbabwe, Journal of the Indian Ocean Region, vol. 13, no. 1, 25-39.

Masingo, R., \& Haraldsson, M., (2010). Across Southern African borders with informal cross border traders, Economic Justice Network of the Fellowship of Christian Councils in Southern Africa, Cape Town.

Matlovičová, K., Mocák, P., \& Kolesráová, J. (2016). Environment of estates and crime prevention through urban environment formation and modification, Geographica Pannonica, vol. 20, no. 3, 168-18o.

Meyer, D., (2013). Exploring the duality of structure and agency - the changing dependency paradigms of tourism development on the Swahili coast of Kenya and Zanzibar, Current Issues in Tourism, vol. 16 no. 7-8, 773-791.

Mitchell, J., \& Ashley, C., (2010). Tourism and poverty reduction: Pathways to prosperity, Earthscan, London.

Muzvidziwa, V.N., (1998). Cross-border trade: A strategy for climbing out of poverty in Masvingo, Zimbabwe, Zambezia, vol. 25, 29-58.

Muzvidziwa, V.N., (2010). Double-rootedness and networking among urban migrants in Zimbabwe, Journal of Sociology and Social Anthropology, 1, no. 1-2, 81-90.

Nunez, R.J. (2009). Circular Migration and Employment in Southern Africa, TIPS Working Paper Series 2009-06, Johannesburg.

Nunkoo, R., Smith, S.L.J., \& Ramkissoon, H. (2013). Residents' attitudes to tourism: A longitudinal study of 140 articles from 1984 to 2010, Journal of Sustainable Tourism, vol. 21, 5-25.

Oppermann, M., (1993). Tourism space in developing countries, Annals of Tourism Research, vol. 20, 535-556.

Oppermann, M., (1998). Tourism space revisited, Tourism Analysis, vol. 2, 107-118.

Peberdy, S., (2000a). Border crossings: Small entrepreneurs and informal sector cross-border trade between South Africa and Mozambique, Tijdschrift voor Economische en Sociale Geografie, vol. 91, 361-378.

Peberdy, S., (200ob). Mobile entrepreneurship: Informal cross-border trade and street trade in South Africa, Development Southern Africa, vol. 17, 201-219.

Peberdy, S., (2002). Hurdles to trade? South Africa's immigration policy and informal sector cross-border traders in the SADC, Paper presented at Workshop on Regional Integration, Poverty and South Africa's proposed migration policy, 23 April, Pretoria.

Peberdy, S., (2007). Monitoring small scale cross border trade in Southern Africa, A report for the Regional Trade Facilitation Programme, Southern African Migration Project, Johannesburg.

Peberdy, S., (2013). Gauteng: A Province of Migrants, Gauteng City-Region Observatory Data Brief No. 5, Johannesburg.

Peberdy, S., (2016). International Migrants in Johannesburg's Informal Economy, Southern African Migration Project Migration Policy Series, No. 71, Waterloo, Canada.

Peberdy, S., (2017). Competition or Co-operation? South African and Migrant Entrepreneurs in Johannesburg, Southern African Migration Project Migration Policy Series, No. 75, Waterloo, Canada.

Peberdy, S., \& Crush, J., (1998). Trading places: Cross-border traders and the South African informal sector, Southern African Migration Project, Migration Policy Series No. 6, Kingston, Canada.

Peberdy, S., \& Crush, J., (2001). Invisible trade, invisible travellers: The Maputo Corridor Spatial Development Initiative and informal cross-border trading, South African Geographical Journal, 83, 115-123.

Peberdy, S., \& Rogerson, C.M., (2000). Transnationalism and non-South African entrepreneurs in South Africa's small, medium and micro-enterprise (SMME) economy, Canadian Journal of African Studies, vol. 34, $20-40$.

Peberdy, S., \& Rogerson, C.M., (2003). South Africa: creating new spaces? In: Kloosterman, R., Rath, J. (eds), Immigrant Entrepreneurs: Venturing Abroad in the Age of Globalization, Berg, Oxford, 79-99. Oxford, Berg.

Peberdy, S., Crush, J., Tevera, D., Campbell, E., Zindela, N., Raimundo, I., Green, T., Chikanda, A., \& Tawoodzera, G. (2015). Transnational entrepreneurship and informal cross-border trade with South Africa, In: Crush, J., Chikanda, A., Skinner, C. (eds.), Mean Streets: Migration, Xenophobia and Informality in South Africa, Southern African Migration Programme, Cape Town, 207-228.

Richter, M., Chersich, M.F., Vearey, J., Sartorius, B., Temmerman, M., \& Luchters, S. (2014). Migration status, work conditions and health utilization of female sex workers in three South African cities, Journal of Immigrant Minority Health, vol. 16, 7-17.,

Rogerson, C.M.(2002). Urban tourism in the developing world: Thecase ofJohannesburg, Development Southerm Africa, vol. $19,169$. 
Rogerson, C.M., (2004). Regional tourism in South Africa: A case of 'mass tourism of the South', GeoJournal, vol. 60, $229-237$.

Rogerson, C.M., (2006). Pro-poor local economic development in South Africa: The role of pro-poor tourism, Local Environment, vol. 11, 37-60.

Rogerson, C.M., (2011). Urban tourism and regional tourists: Shopping in Johannesburg, South Africa, Tijdschrift voor Economische en Sociale Geografie, vol. 102, 316-330.

Rogerson, C.M., (2013). Urban tourism, economic regeneration and inclusion: Evidence from South Africa, Local Economy, vol.28, no. 2, 186-200.

Rogerson, C.M., (2015a). The uneven geography of business tourism in South Africa, South African Geographical Journal, vol. 97 (2), 183-202.

Rogerson, C.M., (2015b). Unpacking business tourism mobilities in sub-Saharan Africa, Current Issues in Tourism, vol. 18, no. 1, 44-56.

Rogerson, C.M., (2016a). Responding to informality in urban Africa: Street trading in Harare, Zimbabwe, Urban Forum, vol. 27, 229-251.

Rogerson, C.M., (2016b). Progressive rhetoric, ambiguous policy pathways: Street trading in inner-city Johannesburg, Local Economy, vol. 31, no. 1-2, 204-218.

Rogerson, C.M., (2018). Unpacking the changing economic geography of Gauteng's tertiary sector, In: Cheruiyot, K. (ed.), The Changing Space Economy of City-Regions, Springer International, Cham, 157-184.

Rogerson, C.M., \& Letsie, T., (2013). Informal sector business tourism in the global South: Evidence from Maseru, Lesotho, Urban Forum, vol. 24, no. 4, 485-502.

Rogerson, C.M., \& Rogerson, J.M. (2014). Urban tourism destinations in South Africa: Divergent trajectories 2001-2012, Urbani izziv, vol. 25 (Supplement), S189-S2O3.

Rogerson, C.M., \& Rogerson, J.M., (2015). Johannesburg 2030: The economic contours of a 'linking global city', American Behavioural Scientist, vol. 59, 347-368

Rogerson, C.M., \& Rogerson, J.M., (2016). Intra-urban spatial differentiation of tourism: Evidence from Johannesburg, South Africa, Urbani izziv, vol. 27, no. 2, 125-137

Rogerson, C.M., \& Rogerson, J.M., (2017). City tourism in South Africa: Diversity and change, Tourism Review International, vol. 21, no. 2, 193-211.

Rogerson, C.M., \& Rogerson, J.M. (2018). Africa's tourism economy: Uneven progress and challenges, In: Binns, T., Lynch, K., Nel, E., (eds.), The Routledge Handbook of African Development, Routledge, Abingdon, 545-560.

Rogerson, C.M., \& Saarinen, J. (2018). Tourism for poverty alleviation: Issues and debates in the global South, In: Cooper, C., Volo, S., Gartner, B., Scott, N. (eds), The SAGE Handbook of Tourism Management: Applications of Theories and Concepts to Tourism, Sage, London, 22-37

Rogerson, J.M. (2011a). The limited services hotel in South Africa: The growth of City Lodge, Urban Forum, vol. 22, p. 343-361.

Rogerson, J.M. (2011b). The changing all suite hotel in South Africa: From 'extended stay' to African condo hotel, Tourism Review International, vol. 15, no1-2, 107-121.

Rogerson, J.M., (2013a). The economic geography of South Africa's hotel industry 1990 to 2010, Urban Forum, vol. 24, no. 3, 425-446.

Rogerson, J.M., (2013b). Reconfiguring South Africa's hotel industry 1990-2010: Structure, segmentation and spatial transformation, Applied Geography, vol. 36, 59-68.

SBP, (2006). Cross-border African shoppers and traders in South Africa: findings From an SBP survey, SBP, Johannesburg.

Slocum, S.L., Backman, K.F., \& Robinson, K.L., (2011). Tourism pathways to prosperity: Perspectives on the informal economy in Tanzania, Tourism Analysis, vol. 16, 43-55.

Smith, R.A., \& Henderson, J. C., (2008). Integrated beach resorts, informal tourism commerce and the 2004 tsunami: Laguna Phuket in Thailand, International Journal of Tourism Research, vol. 10, (3), 271-282.

Tanya Zack Development Planners, Urban Works, Progressus Research \& Development Consultancy, (2017). Cross Border Shopping in Johannesburg's Inner City, The Johannesburg Inner City Partnership, Johannesburg.

Tawodzera, G., \& Chikanda, A. (2017). Linking Harare and Johannesburg through informal cross-border entrepreneurship, African Human Mobility Review, vol. 3., no. 2, 910-942.

Tichaawa, T., (2017). Business tourism in Africa: The case of Cameroon, Tourism Review International, 21 (2), pp. $181-192$.

Timothy, D., \& Teye, V.B., (2005). Informal sector business travelers in the developing world: A borderlands perspective, The Journal of Tourism Studies, vol. 16, 82-92.

Timothy, D., \& Wall, G. (1997). Selling to tourists: Indonesian street vendors. Annals of Tourism Research, vol. 24, no. 2, 322.

Truong, V.D., (2018). Tourism, poverty alleviation, and the informal economy: The street vendors of Hanoi, Vietnam, Tourism Recreation Research, vol. 43, 52-67.

Wahnschafft, R., (1982). Formal and informal tourism sectors: A case study in Pattaya, Thailand, Annals of Tourism Research, vol. 9, 429-451.

Weber, K., \& Chon, K., eds., (2002). Convention tourism: international research and industry perspectives, Haworth Hospitality Press, Binghamton.

Yotsumoto, Y., (2013). Formalization of urban poor vendors and their contribution to tourism development in Manila, Philippines, International Journal of Japanese Sociology, vol. 22, no. 1, 128-142.

Submitted:

20.12.2017
Revised:

15.05.2018
Accepted and published online 18.05.2018 